\title{
WHICH IS THE VOCATIONAL LANGUAGE OF CULTURAL TOURISM IN SERBIA?
}

\author{
Mihaela Lazović \\ The College of Hotel Management, \\ Belgrade, Serbia
}

\begin{abstract}
:
This paper attempts to determine the vocational language used in cultural tourism in Serbia. Being in the centre of intercultural communication, the tourism industry has become the meeting point of different languages and cultures. As a result, an abundant influx of English terms i.e. anglicisms in the Serbian language especially in tourism and hospitality lexicon has been detected. This unique linguistic and cultural phenomenon initiated the linguistic anglomania and became a recognizable status symbol.

The research conducted for this paper has revealed a new hybrid language which sprung out of the ever growing trendy use of English words in the Serbian language especially in the domain of cultural tourism. This hybrid language can be considered a linguistic anomaly which represents a fusion of the English language and the Serbian language. This research has shown that the influence of the English language is incorporated into every linguistic domain of the native language: semantic, pragmatic, grammatical and even morphological.

This phenomenon can be specified as profession-driven use of anglicisms. The reasons for using English terms in Serbian are analysed from the linguistic and sociological point of view.
\end{abstract}

\section{Keywords:}

anglicisms, Serbian translational equivalents, tourism and hospitality terminology, linguistic anglomania

\section{INTRODUCTION}

The research on language and tourism is in its early stages in both linguistics and in tourism studies. Some research has been done within the field of sociolinguistics, where the mentioned authors offer discursive analysis of six different tourism contexts: three about language use and three about language representation (Cohen and Cooper, 1986, p. 554; Heller, 2003; Boudreau and White, 2004, p. 328; Manca, 2008, p. 370; Jaworski and Pritchard, 2005, p. 3, Jaworski, 2009, p. 663).

This paper aims to contribute a unique sociolinguistic and discourse perspective to the field of tourism studies, especially in the domain of cultural tourism. It focuses on the role of language and communication in cultural tourism. Furthermore, the paper analyses what cultural tourism reveals about language and languages today.
Correspondence:

Mihaela Lazović

e-mail:

laz_13@yahoo.com 
The paper brings to light a whole a new field of "sociolinguistics of tourism" (Thurlow and Jaworski, 2010, p. 1) as well as discursive strategies that reinforce language ideologies of cultural tourism.

Sociolinguistics is a contemporary scientific discipline which considers the role of language in the broader representation of cultural and other identities in tourism destinations (Coupland 2003, p. 420; Cos, 2006, p. 15). Thus, the sociolinguistic scope refers to the ways in which the elements of a language context are used, both intentionally and unintentionally, to achieve social goals.

The ties between language and tourism are unbreakably strong. Thus, it is only natural to study them side by side, to study their mutual influences which shaped both cultural and language changes of our modern times.

Likewise, tourism and culture are intertwined in the sense that every touristic experience, every voyage has some elements of a local culture. Local culture is a vital element of every touristic destination. The term culture has been defined many times in the relevant literature. In this paper the term culture will entail all human creativity, both material and spiritual. In the broad sense, culture comprises people's beliefs, ideas and values, their behaviour and lifestyle, customs, history and heritage as well as everything people create: works of art and objects, cultural products, gastronomy, architecture... Thus, there is a logical and natural connection between culture and tourism. Needless to say that cultural tourism is focused on cultural attractions which are the basic reason for traveling. It is interesting to point out that, today, tourists are not simply interested in cultural heritage, history and sightseeing, they are interested in modern and contemporary elements of culture which entail contemporary arts, visual arts, contemporary architecture, literature, music festivals, film, sports. What is more, nowadays, tourists want to actively participate in the cultural activities of regions and countries they visit. In other words, a contemporary tourist wants to actively and interactively engage in culture with the aim to acquire new educational, creative and entertaining experiences.

All these cultural domains have one and only one thing in common, and that is the language. The basis of every culture is the language which is used to express all the elements of any culture.

The core or the primal aim of tourism, in general, as well as cultural tourism, is to attract tourists, guests and customers and, in such a way, provide a significant income. The basic means for achieving this goal is language. Namely, the tourist's first encounter with a destination is through language, written or spoken. Specifically, tourists usually read something about a certain destination, most often on the internet, sometimes they hear stories from friends and family.

The research conducted for this paper has revealed the actual language of cultural tourism in Serbia as well as how this language is used with the aim to attract tourists, guests and customers.

Furthermore, it is important to point out that the technological advancement of the modern times brought about a unique linguistic, sociological and cultural phenomenon which resulted in a wide use of English words in almost every aspect of our lives: in the language of media, fashion, as well as science and technology and especially in the domain of tourism. Specifically, since the tourism industry is in the epicentre of international and intercultural communication, it represents the meeting point of different languages and cultures. As a result, there is an increasing number of English words, i.e. anglicisms in the tourism discourse in the Serbian language. This tendency can be referred to as profession-driven use of anglicisms which is motivated by the common misconception that the use of anglicisms in professional lexicon is the only authentic and compelling way to express specific terminology, while the existing Serbian words are ignored or even unknown. As oppose to profession-driven, there is a status-driven use of anglicisms which is inspired by young urban people and their unfounded beliefs that the use of anglicisms is modern, posh and smart, because it creates the impression of belonging to a more powerful social group (Prćić 2005, p. 150). In such a way, the growing use of English words in the Serbian language has become a recognizable status symbol.

At this particular juncture, cultural tourism plays a very important or crucial role in the sense that it binds together the profession-driven and status-driven use of anglicisms. In other words, in cultural tourism, the profession-driven and status-driven use of anglicisms are in direct correlation since often the first contact between the guests and hotels or tourist and travel agencies is via the internet or, to be more precise, via tourism websites, or generally, by means of the mass media which is often lead by the ambition of the website creators to attract more tourists and guests. As a result, inspired by status-driven motives, marketing teams started using anglicisms in the field of cultural tourism in order to sound more appealing, modern and contemporary aiming to entice as many tourists as they possibly can. This is why an increasing number of anglicisms appear in the field of cultural tourism. 
Evidently, it has become a global trend to use English words and incorporate them in the everyday as well as professional communication.

\section{RESULTS}

The research conducted for this paper represents a contrastive analysis of words and phrases which originate from the English language, but are adopted or borrowed, and commonly used in the Serbian language to denote professional terminology in the domain of cultural tourism. Such lexical entities or, to be more precise, words, phrases or syntactic constructions are called anglicisms.

The research has shown that, in the cultural tourism discourse, anglicisms are most frequently used in the names of contemporary cultural events taking place in Serbia.

The research is based on a corpus which was extracted from the website of National Tourism Organization of Serbia as well as numerous websites of Serbian tourism and travel agencies, from brochures and other marketing materials (http://www.serbia.travel/dogadjaji/kalendar-dogadjaja). The corpus consists of 300 anglicisms, i.e. English words and phrases used in names of Serbian cultural events. The anglicisms analysed and presented in this paper have the same morphological form as they do on the websites and marketing materials from which the corpus was extracted. These anglicisms are further subcategorized according to their meaning, form and use.

The first group of anglicisms from the corpus consists of examples of English words which have simply been copied into the name of the cultural event and used within Serbian phrases. The anglicisms are used in their original English morphological form without any spelling alternations. In relevant linguistic literature (Prćić 2005, p. 145-146), such angicisms are called raw anglicisms. For example:

1. Međunarodni Blues and Rock Festival "In Wires"

2. Sky Race Sokolov put

3. Filmski festival "Free Zone"

4. Beogradski sajam knjiga $\bullet$ Sajam obrazovanja $\bullet$ Media Market

5. Medunarodni kongres i sajam kozmetike, solarijuma, opreme, Wellness, Spa i nege kose "Dodir Pariza“

6. Medunarodni festival studentskih pozorišta "Urban Fest “

A special curiosity is expressed by the use of quotation marks which are sometimes used in accordance with the norms of the English language (like in the examples 1 and 3) and sometimes in accordance with the norms of the Serbian language (like in the examples 5 and 6, and further down in examples 10, 11 and 14).

Of course, the corpus registers Serbian cultural events which have purely English names. These are also examples of raw anglicisms:

7. NS Winter Fest

8. Balkan Cheese Festival

9. Organic Live Fest

The second group of anglicisms from the corpus consists of examples which illustrate spelling mistakes.

10. Mountain Bike Maraton • "Trail Suva Planina“ Planinski Maraton

\section{Rafting Regata „Proteci Rzavom“}

\section{Art Kamp}

In the above examples, the spelling of the English words has been altered: the English word marathon is misspelled maraton, regatta is misspelled regata, and camp is misspelled kamp. The reasons for this are numerous: the morphological form of the English words may be changed to ease the pronunciation, or to allow for the Serbian suffixes to be added more easily. But neither of these things happened since there are no suffixes and there are other English words (which are underlined in the above phrases) and which are spelled correctly. The third option may be that these occurrences are the writer's mistakes due to his/her ignorance or unawareness of the correct English spelling. There is a forth option, in which the writer intentionally used these words considering them Serbian, but nevertheless using them in noun phrases side by side with English words. 
Another group of anglicisms are the so called obvious anglicisms. Such anglicisms have been more or less incorporated into the Serbian language. They are named obvious since their form is transparent form the English language. The examples 13 and 14 clearly show that obvious anglicisms have just been taken over from the English language and assimilated or, better yet, fused into Serbian without any attempt to be translated. It can be argued that these anglicisms have just been altered on the phonetic level so suffixes can be added to them more easily, like in the example 14.

\section{Smotra oldtajmer vozila}

\section{Međunarodna izložba američkih oldtajmera „America on Route $011^{“}$}

On the other hand, the corpus revealed phrases in the Serbian language which mirror the structure of English phrases. In relevant linguistic literature (Prćić 2005, p. 147), such anglicisms are called hidden anglicisms. For example:

\section{Novembar Vino Fest}

In the example 15, the form, meaning and use of English phrase is incorporated or transferred into the Serbian language. To be more precise, the English phrase structure November Wine Festival is copied into Serbian, with the alternations of the words Novembar and vino which have been translated into Serbian.

The corpus records examples of the use of English words which results in grammatically incorrect structures, like in the following example:

\section{Serbia Fashion Week}

Namely, instead of the noun Serbia, the adjective Serbian should have been used. Needless to say, that there is a Serbian translational equivalent Srpska nedelja mode, where the adjective Srpska is also used. Furthermore, adjectives are also used in other similar phrases like American Fashion week, Italian Fashion Week.

Additionally, there are examples in the corpus where the angicisms are incorrectly used on the semantic level, like in the following examples:

\section{Sajam vina, gastronomije i vinskog turizma "Wine and Fine Fair"}

18. Organic Live Fest

In the example 17, there is a coordinated noun phrase where grammatically both words should be nouns, instead we have the adjective fine which was probably incorrectly used here due to the familiar adjective-noun collocation fine wine which is grammatically accurate. Furthermore, in the example 18, there is a common mistake between the words live and life. Namely, the word live has many meanings, the most important of which is having life ( $a$ live lobster) or broadcast directly at the time of production (a live concert), none of which can be contributed to this phrase. Therefore, it is more likely that the writer meant to say Organic Life Fest where the word life means existence.

On the other hand, there is a lot of repetition of the same words in the names of Serbian cultural events, mainly one and the same word is used in its Serbian and in its English form within the name of a single cultural event. These are all examples of tautology, which is defined as needless repetition of an idea, or word:

\section{Rok festival " Rock Garden"}

\section{Somborski džez festival „Green Town Lazz Fest"}

\section{Međunarodno takmičenje u kuvanju pasulja - Bean Festival}

\section{Umetnička radionica za dizajn nakita "Majdan Art"}

Another curiosity in the corpus is illustrated by a few examples (23 and 24) of non-existent word compounds which appear in names of Serbian cultural events, which were probably coined with the aim to sound appealing and interesting striving to attract as many guests and tourists as possible.

23. Susreti vinara i ugostitelja "Vinogastrofest"

24. Međunarodni bluz i džez festival "Lazztronic"

\section{DISCUSSION}

While reading the examples from the corpus a natural and expected question arises: Which language are the names of Serbian cultural events written in? It is not Serbian, and it is not English. It is obviously something in between. 
These examples are written in a new hybrid language or new sociolect which is the result of the trendy use of English words. This new language can be named Angoserbain (Vasić et al., 2001, p. 1). It represents a random and arbitrary mix of English and Serbian words. This new hybrid language retained some characteristics of the Serbian language, but it contains some new words which have been unnecessarily borrowed from English and frequently poorly incorporated into the Serbian language. The research conducted for this paper has shown that such words are often used without any grammatical and spelling rules, and what is more, without clear and precise meaning. The Angloserbian language can be characterized by unjustified and objectively unnecessary innovations created under the influence of the norms of the English language.

Moreover, this sociolinguistic phenomenon occurs in other languages spoken today. The global expansion of the English language initiated an additional cultural phenomenon which is called "Global angloCOOLture" (Prćić 2005, p. 144). Global angloCOOLture reflects in popular opinions, beliefs, and behavioural patterns typical of people who are consciously or unconsciously adopting and actively using English words, considering themselves to be trendier and socially superior - in other words, more COOLtured.

This discussion arises the everlasting linguistic dilemma: Are language borrowings justified or not? There are many opposed opinions among linguists. It is a well-known fact that any language must evolve and change, and stay up to date with the new scientific and technological advancement. On the other hand, if a language loses its norms and characteristics, it ceases to exist. To be against the influence of the English language upon other world languages including Serbian is pointless, since this is a natural process which started a long time ago and cannot be stopped. What is more, historically speaking, it happened before with other influential and dominant languages like Latin and Sanskrit. On the other hand, forfeiting to this outbreak and leaving it to chance is irresponsible and dangerous.

Whether an anglicism is justified or not is in direct correlation with the objective or subjective need to introduce it into another language, in our case Serbian.

Namely, the subjective need to introduce an anglicism is conditioned by extralinguistic factors, such as sociolinguistic, psycholinguistic and pragmatic factors, since it depends on the person who chooses to use anglicisms. For example, anglicisms are frequently used in the cultural tourism by marketing and management teams with the aim to sound more appealing, modern and contemporary in order to attract more tourists and guests. This is why an increasing number of anglicisms can be found on different touristic marketing materials, brochures, on websites, as well as in actual hotels and tourist or travel agencies.

On the other hand, the objective use of anglicisms is conditioned by purely linguistic factors, especially semantic factors. Specifically, objective anglicisms introduce a new concept, a new idea, or a new meaning into the Serbian language. For example: wellness, fitness, spa, internet, etc. Such anglicisms contribute to the expressiveness of the Serbian language since they denote a notion which did not exist before.

Thus, it can be argued that an anglicism is not justified if a term denoting the same idea or concept already exists in Serbian. On the other hand, an anglicism can be justified if it establishes a new concept or a new meaning which is typically connected to technological advancement as well as modern way of life.

To this end, it is important to point out that contemporary linguists consider language borrowings a normal, necessary and unstoppable modern phenomenon, yet with persistent pleas for scholarly, adequate use, alongside with a sophisticated promotion of the general language culture (Bugarski 1996, p. 18, Klajn 2008, p. 155, Prćić 2005, p. 135).

The research conducted for this paper has revealed that this sociolinguistic phenomenon occurs in professional terminology, including cultural tourism lexicon, mainly because of unfounded beliefs that the English term is the only valid and appropriate. One other reason for using anglicisms would be the ignorance of the user who very often does not know the Serbian translational equivalent. And last but not least, this research has shown that anglicisms are very often used in cultural tourism with the aim to sound more interesting and modern in order to attract more tourists and guests.

Moreover, Thurlow and Jaworski (2011, p. 289) point out language and languages sit at the very core of the tourist experience, its representation and its realization, its enculturation and its enactment. 


\section{CONCLUSION}

This paper presents a unique sociolinguistic and discourse perspective to the field of cultural tourism. To be more precise, it analyses the role of language and communication in cultural tourism. Furthermore, the paper offers a new insight on what cultural tourism reveals about the Serbian language today as well as the influence of the English language on the Serbian cultural tourism lexicon. Most importantly, this research has revealed the actual language used in cultural tourism discourse as well as how this language is used with the aim to attract tourists, guests and customers.

The new era or technological advancement and globalization resulted in an abundant use of English words i.e. anglicisms in almost every sphere of human life, both personal and professional. The research conducted for this paper has proven that there is an increasing number of anglicisms used in cultural tourism professional communication. The core of this research has been the use of anglicisms in the cultural tourism discourse. The research has shown that, in the cultural tourism discourse, anglicisms are most frequently used in the names of contemporary cultural events taking place in Serbia. The research has also shown that anglicisms are often used without any grammatical and spelling rules, and what is more, without clear and precise meaning.

This research has proven that the use of anglicisms in cultural tourism discourse may be conditioned by both linguistic and extralinguistic factors. The extralinguistic factors are usually of sociolinguistic, psycholinguistic and pragmatic nature. Where the users of English words in cultural tourism discourse strive to belong to a more sophisticated social group and appear trendier and socially superior. On the other hand, the linguistic factors that influence the use of anglicisms contribute to the expressiveness of the Serbian language since they denote a notion which did not exist before.

This research has revealed a new hybrid language or new sociolect which is the result of the fashionable use of English words in combination with Serbian words. This new language can be named Angoserbain since it represents a random and arbitrary blend of English and Serbian language. Thus, based on the results of this research, it can be argued that the vocational language of cultural tourism in Serbia is not Serbian, it is not English either, it is something in between - a new hybrid language named Angloserbian. This hybrid language represents a linguistic anomaly which is characterized by a fusion of English and Serbian words and phrases. This research has shown that the influence of the English language can be detected in semantic, pragmatic, grammatical and even morphological linguistic domain of the Serbian language. It can be argued that the Angloserbian language is based on unnecessary modernisms created under the influence of the norms of the English language.

On a global level, the extensive use of English words in languages all over the world has created additional cultural phenomenon named "Global angloCOOLture". Global angloCOOLture has arrived in Serbia as well. It is based on popular opinions, and behavioural patterns of young urban people who often use English words, considering themselves to be modern and socially superior. This belief has been further adopted by tourism marketing teams who consider that by using anglisicms they sound more contemporary and stylish striving to attract, in such a way, as many guests and tourists as they possibly can. Furthermore, this sociolinguistic phenomenon occurs in vocational language of cultural tourism mainly because users of anglicisms consider the English term to be the only acceptable and appropriate, or they simply do not know the Serbian translational equivalent.

\section{REFERENCES}

Boudreau, A., \& White, C. (2004). Turning the tide in Acadian Nova Scotia: how heritage tourism is changing language practices and representations of language. Canadian Journal of Linguistics/Revue canadienne de linguistique, 49(3/4): 327-351.

Bugarski, R. (1996). Strane reči danas: pojam, upotreba, stavovi. O leksičkim pozajmljenicama: zbornik radova sa Naučnog skupa Strane reči i izrazi u srpskom jeziku, sa osvrtom na isti problem u jezicima nacionalnih manjina (str. 17-25). Beograd: SANU.

Cohen, E., \& Cooper, R.L. (1986). Language and tourism. Annals of Tourism Research, 13: 533-563. 
Coupland, N. (2003). Sociolinguistic authenticities. Journal of Sociolinguistics, 7(4): 417-431.

Cos, J.P. (2006). Language, Culture and Tourism: Perspectives in Barcelona and Catalonia. Barcelona: Turisme de Barcelona.

Heller, M. (2003). Globalization, the new economy and the commodification of language and identity. Journal of Sociolinguistics, 7: 473-498.

Jaworski, A. (2009). Greetings in tourist-host encounters. In The New Sociolinguistics Reader, N. Coupland and A. Jaworski (eds), pp. 662-679. Houndmills: Palgrave Macmillan.

Jaworski, A., \& Pritchard, A. (2005). Discourse, Communication and Tourism. Clevedon: Channel View.

Klajn, I. (2008). Purizam i antipurizam u srpskom jeziku. Južnoslovenski filolog LXIV: 153-176.

Manca, E. (2008). From phraseology to culture: qualifying adjectives in the language of tourism. International Journal of Corpus Linguistics, 13(3): 368-385.

National Tourism Organization of Serbia. (2016). Karavan "Moja Srbija". Retrieved September 03, 2018, from http://www.serbia.travel/dogadjaji/kalendar-dogadjaja

Prćić, T. (2005). Engleski u srpskom. Petrovaradin: Alfa graf.

Thurlow, C., \& Jaworski, A. (2010). Tourism Discourse: The Language of Global Mobility. Basingstoke: Palgrave Macmillan.

Thurlow, C., \& Jaworski, A. (2011). Tourism Discourse: Languages and Banal Globalization. Applied Linguistics Review, 2: 285-312.

Vasić, V., Prćić, T., \& Nejgebauer, G. (2001). Du yu speak anglosrpski? Rečnik novijih anglicizama. Novi Sad: Zmaj. 